\title{
The Relationship Between the Religion and the State Between the Western Vision and the Islamic Vision in Its Asian Models
}

\author{
Taha Abdel Aal Taha Mohamed ${ }^{1}$ \\ ${ }^{1}$ Department of Political Science, Faculty of Economics and Political Science, Cairo University, Cairo, Egypt \\ Correspondence: Taha Abdel Aal Taha Mohamed. E-mail: master_taha82@yahoo.com
}

Received: April 5, 2019 Accepted: April 21, $2019 \quad$ Online Published: April 30, 2019

doi:10.5539/ass.v15n5p102

URL: https://doi.org/10.5539/ass.v15n5p102

\begin{abstract}
This study aimed at addressing the relationship between religion and state, by reviewing the evolution of that relationship in the western vision, beginning with the dominance of the Church in the medieval period, and the emergence of the theocratic state, then ideas of secularism, and the conflict between religion and state in the Frame of ideology, Then reviewing a regression in the thesis of the transition to secularism and the emergence of religious presence in the public sphere. On the other hand, the study dealt with the relationship between religion and state in the Islamic vision in its Asian Models. Where the study dealt with the model of the "Madina State" during the era of the Prophet Muhammad (peace be upon him), which is the Islamic model that spread in the Asian Peninsula, which was the basis of Sunni Islamic thought later. The study also dealt with the "Wilayat al-Faqih" model, which forms the basis of Shiite thought in Iran.

The study relied on the descriptive approach that deals with the analysis and description of the phenomenon. This approach was used in this study to trace the development of the relationship between religion and state in the western vision and Islamic vision in its Asian models.

The study concluded with some results. The most important of these was that: the Western vision to a certain extent passed with integration between religion and the state, as embodied in the model of the "Theocratic State" in the Medieval Period, where the church dominated all the political and social affairs of the state. The Western vision also to a certain extent passed with separation between the religion and the state, as embodied in the model of "secularism", where modernity was linked to the non-involvement of religion in politics, The Western vision also passed with the emergence of a regression in the thesis of the transition to secularism, as reflected in the model of "religious presence in the public sphere. Finally, the Islamic vision with its Asian Models witnessed the difficulty of full integration or separation between the religion and the state, as embodied in the model of the "Madina State" during the Prophet Muhammad (peace be upon him), and its thought which is followed by Sunni Islamic thought. And the Shiite "Wilayat al-Faqih" model, which was the origin of a religious mandate for political power, although it differs from the "Theocratic State" model completely.
\end{abstract}

Keywords: religion, religious phenomenon, religious presence in the public sphere, theocratic state, secularism, Sunni and Shiite political thought

\section{Introduction}

The relationship between religion and politics in the western vision are rooted in the emergence of western political thought itself; It has been associated with that thought since the inception of philosophy in the Greek era. Historically, this relationship was explained by two dimensions: the religion and the ideology. Where the religion as the most profound basis of thought and behavior, since emergence of Jewish and Christian traditions, was a legitimate and primary determinant of power and the relationships that result from it. For ideology, the religious authority has been replaced with ideology in western societies, since the Enlightenment. The ideology has removed the authority of the medieval clergy (Note 1), dedicated the concepts of secularism, standards of representation and election to replace the criterion of the holiness of the ruler, and his divine authority. Which made Marcel Gauchet said that: "modern sociological and political theories presuppose that modernity and globalization will reduce the role of religion in societies until it disappears altogether" (Gauchet, 2007, p. 7).

However, this trend did not continue long; with appearance of the concept of religious presence in the public sphere (Note 2) to become a subject of discussion and debate in the last quarter of the twentieth century - 
particularly in the early 1980 s - with the emergence of calls for modernity to fail and secularism to fall in favor of religion. In addition to the emergence of many studies aimed at studying the role of religion in the public sphere, and the presence of religious interest of the media and specialists in the fields of politics, philosophy, sociology and theology... This has helped to happen some developments: the Islamic Revolution in Iran, The rise of "the Solidarity movement" in Poland, the role of Catholic religion in the Sindhina revolution, and other political crises in Latin America, and the return of Protestant fundamentalism to the forefront as a pressing force in American politics (Casanova, 2005, pp. 12-13). Thus, the religious presence within the public sphere was a counterpoint trend to the transition towards secularism, which was one of the most prominent manifestations of Western modernity, which emphasized the importance of separating religion from the state to ensure living within a secular society.

The relationship between religion and politics in the Islamic vision has been examined on two axes: the first addressed the "Madina State" Model, which established by the Prophet Muhammad (peace be upon him). In other words: was the mandate of the Prophet Muhammad in the "Madina State" a religious or political mandate? In this context, the researcher was exposed to four visions: a vision of (adviser Ashmawi), which established for the model of (arbitration not al-Hakamiyyah "God's rule"). This is in addition to the vision of (Dr. Ali Abdul Razek), which is based on the fact that (Islam is a message not state), as well as the vision of (Dr. Muhammad Abed Al-Jabri), which establishes the (El da'wa "Call for Islam" and build the Islamic nation), and finally the vision of (Dr. Ahmed Al-Wa'izi), which establishes the (Religious Mandate) to support The mandate of the jurist in the Shiite thought. While the second axis dealt the relationship between religion and state in Sunni political thought, as well as in Shiite political thought.

\subsection{The Problem of the Study}

The relationship between the religion and politics imposed a major problem requiring further research and scrutiny. The study dealt with this Problem in four directions:

- The first is the integration to certain extent between the religion and politics, so that clerics have the upper hand and control over social and political affairs (and this trend is reflected in the theocratic state in medieval period in Europe).

- The second is the separation to certain extent between the religion and politics, as this is the only way out for modernization, progress and prosperity (and this trend was embodied in secularism).

- The third is a regression in the thesis of the transition to secularism (which is reflected in the religious presence in the public sphere).

- The fourth is the difficulty of full integration or separation between religion and politics and the need to reach a compromise formula and achieve balance between them. This relationship is adapted to the requirements and variables of the times (which is embodied by the Madina state in the prophetic era).

\subsection{The Objectives of the Study}

The study aims at:

1. Determining the relationship between the religion and the state under the theocratic state; and the hegemony of church authority.

2. Highlighting the relationship between the religion and the state under the secular state; and to exclude religion from political life.

3. Reviewing the relationship between the religion and the state in the light of modernity and the emergence of ideology.

4. Determining the relationship between religion and state in light of a regression in the thesis of the transition to secularism and the emergence of the vision of religious presence in the public sphere.

5. Determining the relationship between the religion and the state under the model of the Madina State in the era of the Prophet Muhammad (peace be upon him), and the spread of this model in the Asian Peninsula.

6. Understanding the relationship between the religion and the state under the mandate of the jurist model in the Islamic thought of Shiites in Iran in Asia.

\section{First: The western vision of the relationship between the religion and the state}

The relationship between the religion and the state in the western vision varied between integration to certain extent (the theocracy state, and the domination of the clergy to the rule in Europe in the medieval period) and separation to certain extent between them (the state of secularism), which paved the way for the emergence of 
ideology to replace the religion (the nation state); The power of the Church was replaced by the rule of law under the nation-state. However, religion has returned to prove its role again; through its presence in the public sphere, which represented a regression in the thesis of the transition to secularism. So the study can address patterns of this relationship, as follows:

\section{1- Dominance of Church Authority}

In the medieval period (Note 3), the clergy enjoyed with a broad authority; spiritually by virtue of their function, Politically because of the weakness of kings and emperors; This weakness which led to the collapse of the Western Roman Empire in $476 \mathrm{CE}$, and hence the rise of the clergy and the rise of the Pope in Europe (Tawfiq al-Taweel, 1979, p. 10). The clergy dominated the education and the educational movement. They monopolized the interpretation of the Bible, and condemned everyone who was ignorant of a fact they had never acknowledged before. The truth in their eyes lies in the appearance of the texts of the Bible, which led them to say incorrect scientific views - such as, saying the rotation of the sun around the earth, and helped them that the kings and emperors handed over their policy in the persecution of violators (Ajibeh, 2004, p. 6).

Thus, the clerics set themselves up at that time to know the truth in all matters of religion and the world, and considered that any other opinion without their opinion and contrary to what under their hands of Bible - in their eyes - is not counted, and punished all who went out on them. Thus, the Church tightened its control and imposed control on the outlets of progress and knowledge, hindered thought and progress, and dedicated the doors of knowledge, progress and civilization. Therefore, Europe was in those Middle Ages in darkness and ignorance "Nescience" (Ajibeh, 2004, p. 6), mental thought was idle, and scientific research stagnant; because of those obstacles developed by clerics in the face of science and scientists (Ajibeh, 2004, p. 7).

However, the European mind began to wake up from its slumber to resist the power of the Church and provide profound change what prevailed in the Middle Ages. This change took place in two phases:

The first phase (the 11th to the 15th century):

This phase was in the non-conviction of the leadership of clerics to be the first in the guidance, leadership and thought. Thus the church was criticized by showing the disadvantages of the clergy, and the degeneration of the moral level of clergymen. In addition to the emergence of religious reform movements - the Protestant Movement - led by Martin Luther (1483-1546), who attacked the instruments of forgiveness, the authority of the pope to monopolize the interpretation of the Bible, and demanded the subordination of the clergy to civil authority (Lorimer, 1990, pp. 113-117) which led to the deprivation against him in the year 1520, and his blood was destroyed by a decision of the Imperial Council, as he exposing the internal and external security of the State for the grave dangers (Shennawi, 1982, pp. 380-384).

The Protestant Reform Revolution, which called for the reform of the Christian clergy, was able to impose itself on the European reality by revolutionizing the Church and, in some ways, to reform it in its treatment of certain things. This was aided by some of the changes in the growth of knowledge and science in Europe outside the Church, after the science in the Middle Ages was passing through the men of the church (Ajibah, 2004, p. 66).

\section{The second phase (The 16th century):}

This phase was in the trends to science and the establishment of scientific societies that adopt scientific views, and encourages scientific research based on scientific approaches away from the eyes and thought of the clergy of the Church at the time (Fisher, 2001, pp. 9-10). This phase represented a revolution against the clergy as a hindrance to thought, an obstacle to scientific progress, and a barrier to independent scientific research based on reason and logic. Which paved the way for the emergence of Secularism ideas (Ajibah, 2004, p. 27).

\section{2- The emergence of Secularism ideas}

There is no doubt - according to Pro.Dr Ajibah - that the clergy obstruction of thought and the movement of science in the Middle Ages was the reason for the darkness in Europe, and ignorance, and the European mind suffered a kind of apathy, which had the effect of standing against the clergy and the principles of the Church at the time (Ajibah, 2004, p. 27). And thus contributed to the emergence of secularism (Note 4). where the secular movement initially aimed to get rid of the control of the church on political affairs, and the liberation of political power from any direct or indirect influence by the religious authority, which in turn encourages the scientific movement and ideas contrary to the clergy, who embraced them, and considered it to be an established basis, and its violation was considered a departure from them.

Thus, to a certain extent, secularism is an ideological theory that revolves around what the political system must be through the exclusion of religious institutions (Al-Sawalha, 2014, p. 68). It is one of the most important 
theories that tried to study the relationship between the religion and the state, and to interpret that relationship in a different context than before (the authority of the Church). Where secularism found its first seeds in the clash between science and the Church; which began when Copernicus developed his theory in 1510 on the centrality of the sun and the rotation of the earth and other planets around it. The theory was known not because it was the basis of the new science; it also shattered some of the ideas that dominated in this time about the centrality of the Earth and the rotation of the sun and the planets around it. Copernicus saying the earth revolves around the sun and it is not the center of the universe overcame the theory of Ptolemy-Aristotle (Note 5), the 20-century-old theory of the scientists, which the Church supported for 12 centuries, And made mere questioning of this theory infidelity. So the earth moves and the church is not the center of the universe, but all these years have been wrong. This is proved by "Copernicus" the clergyman - priest of the Church of Frauenburg in Poland - who had been serving the Church for many years (Al-Sawalha, 2014, pp. 66-68).

Thus, the Copernican system not only violated certain principles of Aristotelian philosophy; it also contradicted the Christian theology, which claimed that the earth was the center of the universe, and that the Bible was the ultimate argument which refer to that. Copernicus and his followers did not overlook this. But they worked on strategies to avoid clashing with the texts of theology. Where, Rheticus (1514-1574) - Copernicus first and most passionate follower - wrote a letter in which he tried to reconcile between the Bible and the new Copernican system. In short, it's mean that the clash between the new system of the world and the adopted theological views - a mixture of sacred and traditional Aristotelian texts - constituted a major obstacle to the acceptance of the Copernican system (Note 6), and the clash was inevitable - either in the life of Copernicus or a little later - as happened with Galileo (Al-Sawalha, 2014, p. 68).

The study concludes in this point that the theory of Copernicus contributed to the emergence of a science free of the ideologies and religious beliefs that prevailed in the Middle Ages. And then Copernicus is the author of the first blow that shook the entities of immobility that existed in his time. And his scientific revolution represented fundamental transformation in the western perception of the universe and the place of the individual in it. And It also transcended the limits of astronomy to influence religion, politics, philosophy and human culture at the time.

Thomas Robbins, however, believed that the theories of secularization faced more difficult to respond to critics who regard modern walls between church and state as being subject to various faults through which they can penetrate each other. And the religious institutions often refused to accept their marginal position in the private sphere; they succeeded in carrying out prominent public roles. And religion and politics continue to form all types of symbiotic relations, so that it is difficult to ascertain whether one is witnessing political movements wearing religious clothe or religious movements that take political forms (Robbins and Roberston, 1987, pp. 28-30).

Hence, some criticisms were directed against secularism, as following:

a. The failure of secularism to predict the end of religion and beliefs: as what secularism predicted of the fall of religion and the generalization of secular experience in the non-Western world has been shattered under the reality of the Religious revival since the eighties of the twentieth century. Religion has become public, and has entered the public sphere and all of the media, and sociologists and politicians are paying attention to it (Al-Sawalha, 2014, pp. 83-84).

b. The failure of secularism to predict the marginalization of religion and its decline in the private sphere: as one cannot say that democracy requires the secularism or that on-secular democratic models do not exist in reality. On the contrary, historical experience proves that this tension can be alleviated in practice. Some Countries with a religious majority (Note 7) of all religions (Islam or Christianity..) were able to establish a framework for accommodating religion within political tolerance and democratic civil governance (Italy (Note 8), Chile, Bangladesh, Indonesia) (Al-Sawalha, 2014, p. 85).

c. The failure of secularism to succeed outside the Western world: The argument that secularism has failed in non-Western countries is justified (Al-Sawalha, 2014, p. 86). Turkey has adopted a secular interpretation of democracy, and despite decades of attempts - sometimes by repressive measures - to marginalize religion from the public sphere and political life; those attempts ended in a less democratic state and far from being even secular; on the contrary, religion in Turkish society became more acceptable than ever before (Al-Sawalha, 2014, p. 87).

\section{The conflict between religion and state and the emergence of ideology}

The conflict between the religion and state was emergence with the existence of nation state (the Treaty of Westphalia 1648), where the calls for the transition of Western man from the stage of religious allegiance for the 
church (Religious Authority) to a stage where allegiance was nationalistic (National Authority) increased. In this way, the western man transformed from "believer" to "citizen". By his moving from faith circle to the circle of citizenship, the state was granted complete independence in the secular organization under conditions that did not prevent the citizen from continuing in his relationship with God. This idea was endorsed by the Catholic groups in two words, "God is separate", that is, God does not interfere in the political affairs of mankind, as Pope Pius VII declared in 1906: "Salvation is an individual matter." Portalis explicitly called in 1801: "We must not confuse religion and state - religion is the union of man with the Creator; the state is the meeting of men with one another; but humans need no revelation or vision or supernatural support to meet among themselves. It is enough for them to examine their interests, feelings, strengths and various relationships with their counterparts, that they need only themselves (Al-Sawalha, 2014, p. 69).

The conflict between duty towards God and duty towards the state has historical roots, the conflict that took the form of conflict between the church and the king in the Middle Ages, as a result of the extension of the papal judicial authority to Italy, France, Spain, Great Britain, Ireland and Poland. This authority increased during the reign of Gregory VII (At the end of the eleventh century). Since then, the men of the Church have become a unified body in all Western Europe; they are run by Rome, which seeking the for itself the authority in a disciplined manner, and reconciling whenever there is a conflict between them and those who has worldly authority. The conflict between the church and the state was not merely a conflict between the clergy and other sects; it was a renewal of the conflict between the Mediterranean and the North Barbarian countries, and the unity of the Roman Empire was found to be echoed in the unity of the Church (Russell, 2010, pp. 18-19).

Some Western philosophers and thinkers supported the idea of separation of religion and state. Machiavelli (Note 9) called on temporal rulers to practice their rule in isolation from the Church and the clergy who imposed their hegemony on princes and kings. In the seventeenth century, Hobbes gave justification to the secularism of the state, rejecting the idea of Divine Right; that is, the rule of God. While Montaigne in the sixteenth century pointed out that "there is no fixed and universal truth, including the Christian truth." Descartes, in the seventeenth century, rejected the philosophy of the Middle Ages, and resorted to any authority outside the authority of reason, which led the Church to place his books on the list of Forbidden Books (Al-Sawalha, 2014, p. 69).

Hegel considered that the view of the relationship between the religion and state is linked to the concept of the state itself, which indicates that the state's mission is to protect and secure the life, property and liberty of each of its citizens, to the extent that it does not infringe upon the life, property and freedom of others. This concept of the state makes it an institution that nurtures the need, thus an element for what is spiritual (religion), is the element of right in itself and for itself lies above and beyond the state (Badawi, 1996, p. 176).

Hegel also believed that the state has nothing to do with the self-side of religion; it only cares about external manifestations of religion. The state has nothing to do with different religions, but all religions inside its borders are equal, and it must protect every religion in it, and not interfere in the differences between the religious sects. The clerics have no privileges over other citizens of the state: they must pay taxes like all other citizens; they must comply with the laws of the state; they must be tried in civil and criminal matters according to the laws in force in the state and before the general courts (Badawi, 1996, p. 177).

John Locke, in "the Message of Tolerance", pointed out that: "No one has the right to enter civil and secular rights in the name of religion, so the art of ruling should not contain any knowledge of the true religion. Therefore, religious tolerance requires that the state should not have a religion because the salvation of souls is only for God, and God has not delegated anyone to impose on any person a particular religion. Then the power of the true religion lies in the conviction of reason, which is latent in the depths of man."

John Stuart Mill developed the concept of tolerance in his book "the freedom"; he believed that tolerance would not prevent believing in absolute truth "dogma (Note 10)". that he say: "Religious freedom is practiced only where there is religious indifference, and this religious freedom refuses to disturb its peace in theological conflicts." Even in tolerant countries, there are reservations about tolerance among most religious people. A person may be split into the Church's style, but he will not tolerate tolerance for the Dogma, so it is impossible to criticize the Dogma of the Dogma followers (Locke, 1999, pp. 7-8).

\section{A regression in the thesis of the transition to secularism (The religious presence in the public sphere)}

Scientific discussions on the concept of public sphere have proliferated since Habermas published his book "Structural Transformation of the Public Sphere (Note 11)" in 1989, in which he saw that this public sphere began to emerge in 18th century (Especially the period of the emergence of the bourgeois class to play important roles within the society), especially as a space independent of the state in its modern meaning, and the totality of 
its institutions, so that people can communicate in this field among themselves as independent and free citizens for deliberation and understanding on the common good. Whereas, the controversy over this public sphere was revived in the last quarter of the 20th century, when the phenomenon of "religious revival" and religious engagement in the public sphere was emergence.

Habermas' goal of using the concept of public sphere, invented by the German philosopher Kant, was to characterize the reality experienced by some European societies. This is confirmed by Habermas himself, when he pointed out that the roots of the public sphere are due to many Social institutions in European society during the eighteenth century. in England appeared in magazines, newspapers and cafes. and in France appeared in the Parisian salons after the middle of the century. and in Germany appeared in a modest form in reading clubs. and this public sphere developed this after the mid-eighteenth century to discuss political issues that were in For the past special affairs in the state. and with introducing the political issues in the critical dialogue circle, the public sphere stopped against the state, and as it the field of logic and reason - the only space for discussion and resolution, which does not spoil inequalities of social and political power - it is opposite the authority of the state The historical result of the critical dialogues included in the public sphere was the entry into parliamentary democracy. In doing so, citizens were able to be outside the country authority as critics and observers, and within the state in the form of legislative representatives (Mah, 2000, p. 157).

On the philosophical level, Habermas believes that the distinction between "public sphere" and "private sphere" was rooted in the Greek era, where there was a public space in which liberals were gathered away political institutions, where they discuss the most important events related to their lives (For example, free gatherings to watch Olympic competitions). But, the "private sphere" is all about "household affairs" in terms of wealth and family-run businesses (Habermas, 1989, p. 3).

Thus, when the bourgeois class went out of their private sphere to discuss issues of general interest with other individuals within society, and with the collective spirit of discussion of public issues - as a result of the gap between the state and its citizens, which was an important source of pressure to form the masses to discuss community issues, and the situation in violation of the rules and laws prevailing in society - this facilitated the emergence of the public sphere; as a result of the exclusion of effective political force from engaging in society, and thus the emergence of the state in a different appearance away from the world of daily life, Specially in the separate between the political and private sphere (individual, family and civil society) (Kellner, p. 264).

Habermas identified three institutional standards for the public domain (Khamis, 2013, p.39):

1. Disregard of Status: the neglect of the social status and hierarchy within society, and the emphasis on harmony among individuals, so that the public domain is seen as an objective forum independent of the social centers and ranking within them.

2. Domain of Common Concerns: Before the emergence of the public sphere, the authority of interpretation in the fields of literature, philosophy and art lay in the hands of the state and the Church, and they had the power to monopolize interpretation. However, with the development of societies, cultural production and the transfer and circulation of information have become a common interest of citizens, thus paving the way for other issues to be of common concern.

3. Inclusivity: The public sphere gives opportunity to all individuals without excluding anyone to participate equally in discussions, thus ensuring diversity of visions and exclusion of personal biases.

In the late 1970s and early 1980s, religion did not disappear or did not suffer a decline in the modernity. It was still "vibrant" as it was in the past, especially with the 1979 Iranian revolution - religion was the main driver of it, which made "Michel Foucault" refers to it as the first religious revolution in modern times. As Habermas also pointed out that today's societies should be characterized as post-secular societies. He was recognized that religion would not disappear because of its significant impact on the lives of individuals and the cultural and political arena (Loobuyck \& Rummens, p. 237). In his article "The Clash of Civilizations," Samuel Huntington added that religion is the key factor in the clash of civilizations hypothesis (Koehrsen, 2012, p. 275).

The rise of religious discourse and debate within the public sphere has emerged as a result of contemporary trends in the academic discussions on the role of religion in contemporary society, including Post-Secularity approaches, Its proponents argue that Secularization Theory has its right side. It can be said that European societies - which in the past were an original example of the theory of secularism - have recently become living in the re-emergence of religion. Thus, according to this approach, the continuity of the existence of religion and its increase in public life is evident. Religion today represents a new public role within human societies, and human societies, including European societies, are now living the stage of deprivatization of religion, the 
presence of religion in the public sphere (Koehrsen, 2012, p. 274).

Habermas pointed out that a new era has begun: the "post-secular" era, or the post-secular society, as religion will be an important partner in public debates related to these communities. Habermas also presented a standard thesis on public religion, by that post-secular societies highlighting religious contributions in the public sphere, where religious thought can contribute to public debates about ethical values in contemporary and future societies. Thus Habermas believes that modern societies may find some answers to ethical questions of the present era by listening to the views of the clergy in the general political debate (Khamis, 2013, p.42).

The existence of religion in the public sphere is indicated by through (Koehrsen, 2012, p. 276):

- The existence of religion experimentally in the public sphere in Western societies.

- The increasing presence of religion in the public sphere in modern societies.

- There is a large and growing influence of religion on the prevailing debate.

Despite the emergence of religion in the public sphere, most western thinkers, however, support the religious presence in the public sphere. Jürgen Habermas, Charles Tiller, Judith Butler, Cornell West, etc. agree on the need to preserve the Western secular project with its democratic institutions matured by centuries of the fertile political movement, by exploring the possibility of making a field for religion to participate in the formulation of decisions and policies, leaving long official isolation from the policy that resulted from its privatization and push it into the individual world (Rahim, 2014, p. 201).

\section{Second: Islamic vision of the relationship between religion and state}

Secularism arose in Europe due to certain reasons and circumstances and erroneous interpretations of medieval clergy, which meant the competence of secularism in Europe and its circumstances. Thus, whoever speaks about secularism and wishes to transfer it to Muslim societies undoubtedly ignores those facts. Moderate Islam (based on Quran and Sunnah) is completely different; there is no doctrine in Islam contradict reason or facts. Islam addresses the mind and relies on it to understand religion and Reconstruction the world. It also calls for knowledge and excellence in it. Rather, it considered that thinking is worship and that seeking the knowledge that the nation needs is obligatory (Ajibeh, 2004, pp. 103-104).

Moderate Islam (based on Quran and Sunnah) urged to learn and seek knowledge, as the Messenger of Allah (Peace upon him) said: "Seeking knowledge is an obligation upon every Muslim (Note 12).", and the Messenger (Peace upon him) also said: "Whoever travels a path in search on knowledge, Allah will make easy for him a path to Paradise (Note 13)." Rather, the Islam has made it obligatory for every Muslim, as God has honored the knowledge that he has opened his Quran (holy book) in the first Surat: "Read in the name of your Lord Who created (Note 14)". And the confirmation of the Muslim commitment to take the reasons of science and knowledge the second Surat in Quran came linked with the science: "Noon. I swear by the pen and what the angels write (Note 15)". As God Almighty has revealed the virtue of the scholars, saying: "Allah will exalt those of you who believe, and those who are given knowledge, in high degrees (Note 16)" And God Almighty said: "Say: Are those who know and those who do not know alike? (Note 17)" Thus, it is obvious the interest of Islam in science and scientists, and its urged to scientific progress, and it did not stand in the face of pioneers of progress, but it make their quest is a blessing for the owners.

Moderate Islam (based on Quran and Sunnah) does not know the priesthood, nor does it have a priestly class that monopolizes religion, controls consciences and closes to the people the door of God except by them. They issues decrees of deprivation or instruments of forgiveness. But one in Islam does not need a means between him and his Lord, his Lord in Islam is closer to him than the cord vein, and religious scholars in Islam are only experts in their specialty, due to them as is due to everyone who is aware of his knowledge, as God Almighty said: "and none can inform you like the One Who is Aware (Note 18)", and God Almighty also said: "so ask the followers of the Reminder if you do not know (Note 19)".

Research on the origins of the relationship between religion and state can be initiated in Islamic political thought by asking the following question: Is the Prophet Muhammad form a state or not? And whether this state is religious or a state based on religion and emanating from it and its orientations, or was this state the result of the will of the people? What is the relationship between religion and state in Sunni thought? What is the relationship between religious and state in Shiite thought?

Thus, the relationship between the religion and the state in the Islamic vision can be monitored through two dimensions. The first dimension is the exposure to the various visions that explained the relationship between the religion and state in the era of the Prophet Muhammad (Peace upon him), The second dimension is the 
relationship between the religion and the state in Sunni and Shiite political thought, as follows:

\section{1- The relationship between the religion and the state in the era of the Prophet Muhammad (El-Madina State)}

According to history, the Prophet Muhammad (Peace upon him) after his migration to El-madina called the tribes to Islam, and established an agreement centered in El-madina (Ibn Hisham, 1990, pp. 143-145), which influenced many analyzes in Islamic political thought about this concentration, and on the leadership of the Prophet Muhammad (Peace upon him), Is this leadership type of political mandate that Emanating from the execution of divine commands, or is the Prophet merely a religious leader, or was that political mandate merely a historical event imposed by certain circumstances and not an invitation to form a religious state?

Thus, the relationship between religion and state in the era of the Prophet can be dealt through the introduction of four visions that explain whether the leadership of the Prophet Muhammad (Peace upon him) is religious or political leadership, and whether the Prophet has formed a state or not, as follows:

\section{a- The relationship between religion and state in terms of "(Islam is a message not state" vision}

The origin of this vision of the relationship between religion and state in Islam was introduced by Dr. Ali Abdul Raziq in his book "Islam and the origins of governance," when he pointed out that the leadership of the Prophet was a religious leadership emanating from his message and his prophecy concludes once his death, and then it is not subject to succession After him (Note 20). As for the caliphs after the death of the Messenger of Allah, represented the political leadership and has nothing to do with religious leadership. They formed the Arab state, drawing on the religious da'wa "Call for Islam" of the Prophet in this matter. As the leaders of this newly established state considered themselves the successors of the Prophet; that is, Muslims imagine that their leadership is on behalf of the leadership of the Prophet, but the Prophet did not have political leadership and did not form the state or government (Abdul Razek, 1925, p. 57).

Abdel Razek is based on his vision that the Prophet's leadership was lacking in the simplest systems of a government, where there was no body of accountants for income and consumption, nor was it to control internal and external affairs, and this type of the systems of the government or the state and its necessity and the fruit of life Prophecy and its simplicity do not represent a barrier to the employment of such services and systems. Accordingly, the loss of these matters indicates that the Prophet did not form a state or a government, and therefore the Prophet's message was not comprehensive for the establishment of the state (Abdul Razek, 1925, p. 45).

Accordingly, the prophet's mandate over the nation, which was referred to in the verse: "The Prophet has a greater claim on the faithful than they have on themselves (Note 21)" is a mandate of message, not a political mandate of some kind held by kings and sultans. Abdul Razek is based on the Prophet's lack of government on the basis of adhering to the verses that limited the Prophet's right to the message and evangelization and warning, including: "I am nothing but a warner and the giver of good news to a people who believe (Note 22)" , And the Almighty God says: "and nothing rests on the Messenger but clear delivering (of the message) (Note 23)", And the Almighty God says: "I am only a mortal like you; it is revealed to me that your god is one Allah (Note 24)". And the Almighty God says: "You are only a Warner (Note 25)". If the Prophet had the government, not the message, it would have been necessary to refer to this right to rule in these verses.

The study concluded that the Prophet was only a messenger of a purely religious da'wa "Call for Islam" to the religion, which is untainted by a king's inclination and no call to a state, that he was not king and did not form a government, did not establish a kingdom. Thus, Islam is a message, not a state.

\section{b. the relationship between religion and state in terms of (arbitration not al-Hakamiyyah "God's rule")}

The origin of this vision of the relationship between religion and state in Islam was introduced by adviser Ashmawi in his book "Political Islam", where he built his vision on his saying: "God wanted Islam to be a religion, people wanted it to be a policy, and religion was a universal for all mankind. But, The policy limited to a temporary local tribal. The religion sees in man the finest and the highest of what he can reach, and politics provokes the lowest and the lowest that can fall to him. And the practice of politics in the name of religion or practice religion in the political style turns the religion into endless wars.. And conflicts do not fade.. Besides, the policy limit the goals in the positions and mix goals with spoils and the conscience spoils with the offers (al-Ashmawi, 1996, p. 17)." Therefore, His vision suggests that the government of the Messenger of Allah was in fact the government of God and his ruling, not the ruling of the Prophet and his government. The Government of the Prophet was not a matter of political jurisdiction; it was not the "Government of ruling" but the "Government of Arbitration".

Al-Ashmawi refers to some historical theocratic forms of government, as follows: 
- The Governor of God at the Pharaohs: through the belief that prevailed in ancient Egypt by consider the rulers as God, where the ruler represented the shadow of God on earth, which made him a theological position, and receives his political provisions from God. Thus, he enjoy sanctity. The rulers are gods and the people are servants.

- The divine rule of the medieval clergy: through the existence of sacred rights to the rulers in the rule of the land, as it was in the theocratic state in the Middle Ages, which ruled by the clergy.

- Ruling on the successors of the Umayyad and Abbasid era: The idea of "ruling of God" was introduced into Islamic political thought for the first time by the Kharijites by means of an incorrect interpretation of the verse: "the judgment is only Allah's (Note 26)" Then the Umayyad and Abbasid Caliphs used this belief Their own political purposes. Muawiyah said: "The land of God. I am the successor of God, what I took that is for me, and what I left that is for the people thanks to me," and it is apparent that the fallacy in his saying came from the same as the successor of God, no successor to Khalifa "the successor" of Khalifa of Khalifa the successor of Allah, The term caliph, meaning succession of a person to his predecessor and those who preceded him in time or order. As the second Abbasid caliph al-Mansur said in his speech: "O people, we have become leaders for you, and who protect you. We judge you with the truth of Allah, and his power that he has given us. I am the successor of Allah in his land and his protector over his money (al-Ashmawi, 1996, pp. 50-52)."

However, al-Ashmawi points out that al-Hakamiyyah (Note 27) (God's rule) is realized in the real sense of the word - in the time of the Messenger of Allah "Muhammed", and in this type of rule; God is the Ruler in fact not the Messenger of him, In every event, the revelation came with the divine judgment of this event, as God has been watching the situation as well. Thus, there was no judgment of the Prophet but there was arbitration by him for the believers; those who made him ruler and judge in their various affairs, and who accepted his rule and judgment not only at the apparent level but also in the subcontinent (Note 28).

The peculiarity of this type of government is that the right to practice power is a juridical right of the ruler not to be transferred to others, as in the case of prophecy and message which are not transmitted to the children by inheritance (Note 29). As, a Political power and jurisdiction are not based on authority and governance but on the basis of arbitration. It is meant by the government of arbitration that the Muslims were going to the Prophet to judge in their cases, and in the provisions of the Prophet, God Almighty was an observer of his Messenger guide him, and verses that indicate the arbitrariness of the Prophet: "But no! by your Lord! they do not believe (in reality) until they make you a judge of that which has become a matter of disagreement among them, and then do not find any straitness in their hearts as to what you have decided and submit with entire submission (Note 30)", and God says also, "therefore if they come to you, judge between them or turn aside from them (Note 31 )".

In summary, the arbitration of the government is specific to the Messenger of Allah "Muhammed", as the government becomes after him for the Muslims, so that its form and content and elements correspond to the conditions of Muslims and the conditions of election it by Muslims.

\section{c- The relationship between religion and state in terms of (building of the Islamic nation) Vision}

The origin of this vision is introduced by Dr. Muhammad Abed Al-Jabri in his book "Religion, the State and the Application of Sharia.", He saw that the goal of the Prophet in the Madina was to build the nation, not to build an Islamic state; when he was fighting he did not do so as a political leader or military commander of a state, but because he is a religious advocate and publisher of a new religion. The prophet avoided naming him the King or the President. He was not a leader or a political leader who made his effort in worldly social and economic matters, but his work was on the Hereafter issues of the Muslims (Note 32).

Al-Jabri based his argument on the following (Al-Jabri, 1996, pp. 13-18):

- In the time of the Prophet Muhammad, the Arabs did not have a king or a state; their political system in Makkah and Madina was a tribal system, and did not reach the state which has land and inhabitants of that land and a central authority for people in their various social affairs.

- $\quad$ The prophet Muhammad avoided naming him king or president of state; however, his quest was focused on the dissemination of religious ethics and social behaviors provided by the religious El da'wa "Call for Islam".

- There is no mention in the Qur'an to the Islamic state; but it pointed to the Islamic nation, in the verse: "You are the best of the nations raised up for (the benefit of) men (Note 33)", and there is no evidence in the Qur'an for the Muslims to build a state or form the government established by the Prophet and their 
harmony with them. Therefore, there was no self-demand of the political mandate by the Prophet.

- $\quad$ The "state" became popular as a political term in the time of the Abbasids; what existed prior to that was the "Nation of Islam". After the transfer of power from the Umayyads to the Abbasids, their tongues said: "This is our state", Demonstrate the interrelationship between religion and state, the centrality of the state and its centrality to the nation.

During the call of the prophet Muhammad at the beginning of the "Islamic Ummah (nation)" appeared, but this call ended after the formation of a special political system called the Islamic State, and this happened during the time of the Abbasid government, the Muslims viewed the Islam and the call of Muhammad as religion Seal, and were not to look at it as a state, all their efforts were focused on preserving religion and the survival of the Islamic Ummah (nation), not on preserving the political system and the newly established state. That is, they were aiming to establish the entity of the Muhammad nation; not by stabilizing their entity through the stability of the political system called the Islamic state and its continuation. They also did not see that the nation and the social entity depended on its existence to form a political system. In the beginning they focus on the creation of the Islamic nation, but the situation developed and integrated later into the call for the establishment of a religious state (Al-Jabri, 1996, pp. 21-22).

\section{$d$ - The relationship between religion and state in terms of "the religious state" Vision}

The origin of this vision introduced by Dr. Ahmad al-Wa'izi, the Shiite thinker in his book "The Religious State: Reflections on Islamic Political Thought", in which he paves the way for the justification of the rule of the Faqih (jurist in religion). He sees through his vision that the Prophet established a political system fit for the nature of the tribal system, which was prevalent. and therefore he put the basis for the existence of an Islamic state, where he pointed out that the form of the modern state as it is customary (land, people live on it, and the central authority issued orders) was not present in the Arab tribes in the past, as some tribes were departed and therefore missing the element of land, And the union of some tribes at one stage imposes the insatiability of the people element, and the private social tribal system had imposed a pattern of political power is different from what it is today (al-Wa'izi, 2002, p. 148).

Therefore, because of the absence of the Arabs to the organized government and the political authority, and adopted them on the tribal system; from the point of view of Dr. al-Wa'izi, the Prophet established a state and government commensurate with his era and time, not with the concept of the modern state. And the most important historical evidence for that, the following today (al-Wa'izi, 2002, pp. 151-154):

- The Prophet established unity between tribes and reconciliation between them, including the formation of a political unity and a kind of common interests and benefits.

- The prophet made the madina the center of his government and from there he sent rulers and governors to other regions.

- The Prophet's imposition of penal sanctions on the retarded and criminals of some Islamic legislative laws, and he not limited to the Day of Judgment punishment.

- The existence of the expression of political power and government in the language of the Qur'an, as in the verse: "and take counsel with them in the affair (Note 34)", and the verse: "and their rule is to take counsel among themselves (Note 35)". If the leadership of the Prophet Muhammad in the (command) is competent religious leadership will not make sense for advice, since the command mentioned in the two verses is a reference to the measure and the political decision. And therefore the political mandate that the prophet Muhammad had and expressed by "command" can be achieved by the Caliphate after his death. Abu Bakr the first caliph after the death of the Prophet said: "Muhammad went to his path, and this matter need the one who is doing it" and said in another place: "I wished that I asked the Messenger of God in the matter, to avoid dispute after him."

In the view of al-Wa'izi, the Prophet's government existence and convince with its originality in the religious teachings, and the evidence of this, the following (al-Wa'izi, 2002, pp. 155-158):

- The inclusion of Islam on the laws cannot be applied in the affairs of society without the religious state.

- $\quad$ Although the Holy Quran did not explicitly impose the establishment of a religious state on Muslims; but set a series of duties in their receivables cannot be performed and established without the establishment of an Islamic state.

- Many Koranic verses prove the political mandate of the Prophet Muhammad and affirms it and demands the believers to obey the orders of the Prophet, as in the verse: "The Prophet has a greater claim on the 
faithful than they have on themselves (Note 36)", where the word "has a greater claim" in this verse the most possessive of the mandate, which indicates that the mandate of the Prophet advanced to all states in the community. And the God's saying: "Only Allah is your Vali and His Messenger and those who believe, those who keep up prayers and pay the poor-rate while they bow(Note 37)", In some accounts, it has been stated that this Vali is a political mandate.

Al-Wa'izi concludes that the Prophet Muhammad established a state in the Madina based on the mandate granted to him by God in terms of the right of the mandate, and this state, although it was coupled with the general satisfaction of Muslims, but its basis was found in religious teachings. In other words, the state of the Prophet was based on authority of religion in all political matters, in the sense that the right of ruling and the principle of the legitimacy of the political mandate were also derived from religion (al-Wa'izi, 2002, p. 164).

\section{2 - The relationship between religion and state in Sunni and Shiite political thought}

In this context, it is possible to address the relationship between religion and state in both Sunni and Shiite thought, as following:

\section{a- The relationship between religion and state in Sunni thought:}

Monitoring the Sunni political thought throughout history, we find that the relationship between religion and state was based on the theory of succession, where this thought was influenced by the work of the friends of the prophet Muhammad in the origin of Islam and religious texts, and according to the perception of the Sunnis there are no explicit texts and teachings in the Quran and Sunnah on how to elect the Caliph And the conditions that he need to be met. therefore this matter left to the jurisprudence of the nation. And then they realize that the authority in the appointment of the Caliph are Ahlil hall wal aqad (the people of solution and contract). As al-Mawardi said, in addition to choosing the people of the solution and the contract for caliph, the former caliph appointment the next califa, based on the way in which the second caliph Omar ibn al-Khattab was elected. Al-Mawardi said: "The imama is held in two ways: one by choosing the people of solution and contract... second: The imam may delegate to the imam after him, and he does not need the testimony of the people of the solution and the contract, and that is because Abu Bakr choosed Omar ... (Al-Mawardi, 1989, pp. 6-11)".

Abu Hamed al-Ghazali saw with the need for a system of imamate or caliphate in a different manner, where he saw that the order of religion was a group of the purposes of the legislator, and is linked and dependent on the order of the world of people, It is thus deduced that the order of the world of people is obtained only by the presence of an imam who is an object of obedience. Al-Ghazali presents the times full of disorder as a testament to his opinion, where the order of the people's world is broken because of the death of the sultans and leaders, and their money and security become vulnerable to attack and targeting (al-Ghazali, 2003, p. 170.).

\section{$B$ - The relationship between religion and state in Shiite thought:}

Shiites believe that the infallible imams are the deputies of the Prophet Muhammad and his inherits in all affairs except to receive the revelation. The imams do not refer to the political mandate and the mundane presidency and to the succession of the Prophet in managing the affairs of society, They also have the moral and religious mandate for the society, as well as the Shiites view: they are the real successors of the Prophet Muhammad and his true preachers.

The issue of imamate among Shiites is not a matter of jurisprudence related to society and its administration and political mandate, It is a matter of speech mixed with faith. In the Shiites thought unbelief in the imamate of the infallible imams is a denial of religion, ignoring some of its texts and teachings, and on this basis the case was as the cornerstone of the Shiites, and the belief of this was the basis of this doctrine (al-Wa'izi, 2002, P. 194). Thus, the political system presented and accepted (not agreed) from the point of view of Shiite scholars who believe in the religious state is the system of wilayat alfaqih (mandate of the jurist).

Where the Shiite thought sees that the state that has proven to the just jurists in public and social matters is a kind of mandate contained in the verses and narrations of the Prophet Muhammad and the infallible imams, and based on the God in verse: "Only Allah is your Vali and his Messenger and those who believe, those who keep up prayers and pay the poor-rate while they bow (Note 38)". In supporting the rule of the Jurist, Muhammad bin al-Nu'man al-Baghdadi, nicknamed Shaikh al-Mufid (413 AH), one of the most prominent Shiite Jurist, said in his book Al-maknaa (convincing): "The establishment of penalty is the authority of the Sultan of Islam appointed by God, and they are the imams of guidance from the family of the Prophet Muhammad, Or those who they appointed of the princes and rulers, and they authorized the consideration of it to the Jurists of Shiites as possible (al-Wa'izi, 2002, p. 220).

This is an explicit statement that the imams as sultans of Islam can, in their lifetime, appoint governors and rulers 
to establish divine penalty. They have delegated this position in the era of the absence to Shiite jurists, and the mandate to carry out the divine penalty goes beyond the stages of jurisdiction over disputes; Is one of the political affairs of the state.

\section{Results}

The relationship between religion and politics has been limited in Four trends:

- The integration to certain extent between religion and politics as it was in the Middle Ages under the theocratic state dominated by the Church. However, there was a coup against the Church during the Protestant Revolution led by Martin Luther, because some ideas of the Church were contrary to what science proved, as well as an attempt to get out of the circle of thought set by the Church, which placed restrictions on scientific life at the time.

- The separation to certain extent between religion and politics, as in the secular state, where the thesis of separation between religion and state was promoted, and that the spread of secularism would lead to modernity, and thus religion was replaced by ideology.

- However, this did not stand long as the writings of the religious presence in the public domain emerged by its pioneer Habermas, and emergence of a regression in the thesis of the transition to secularism (which is reflected in the religious presence in the public sphere).

- The difficulty of full integration or full separation between the religion and the state, which was in the Islamic vision through the model of Al-madina state in the Prophet Muhammad era, which spread in the Arabian Peninsula. And the model of the mandate of the jurist, which prevailed in the Shiite ideology in Iran. Even if Shiite thought saw the religious mandate of the infallible Imamate, it did not promote the concept of a theocratic state that spread in the Middle Ages.

\section{Recommendations}

- The need for studies to examine the relationship between religion and politics from a broad perspective that includes a broader view of that relationship.

- Conducting research and scientific studies on the model of theocratic state and determine the reasons for its failure.

- Conducting Research and scientific studies to determine whether the model of secularism is the ideal model for the West, where religion has been replaced by ideology.

- Researching on a regression in the thesis of the transition to secularism, and the emergence of the trend of religious presence in the public sphere, which promoted the failure of secularism.

- Increasing research and scientific studies on the "model of Medina state", which was founded by the Prophet Muhammad, especially the study of Al-madina document, which established a comprehensive constitution to regulate life at the time.

- Conducting studies on the mandate of the jurist in the Shiite thought, and the classification of the relationship between religion and state in Shiite thought, to determine its position among the four trends mentioned in the study.

\section{References}

Abdul Razek, A. (1925). Islam and the Origins of Governance: A Study on the Caliphate and the Government in Islam. Egypt Press, Cairo.

Ajibeh, A. (2004). The Impact of the Church on European Thought. Dar El-Afaq El-Arbia, Cairo.

Al-Ashmawi, M. S. (1996). Political Islam. Madbouli Library, Cairo.

Al-Ghazali, A. (2003). Moderation in belief. Dar Ibn Qutaiba, Beirut.

Al-Jabri, M. (1997). Religion and the State and the Application of Sharia. Center for Arab Unity Studies, Beirut.

Al-Mawardi, A. (1989). Provisions of the Sultan and the Religious States. Dar Ibn Qutaiba, Kuwait.

Al-Sawalha, A. M. (2014). Religion and State in Israel: A Study in Jewish and Democratic Duality (Ph.D, FEPS). Cairo University.

Al-Taweel, T. (1979). The Story of the Conflict between Religion and Philosophy. The Arab Renaissance House, Cairo.

Badawi, A. (1996). Philosophy of Law and Politics at Hegel. Dar Al Shorouk, Cairo. 
Casanova, J. (2005). Public Religions in the Modern World. TR: Arab Organization for Translation, Center for Arab Unity Studies, Beirut.

El-Wa'zi, A. (2002). The Religious State: Reflections on Islamic Political Thought. TR: Rajaballah, H. Dar al-Ghadeer, Beirut.

Fisher, H. (2001). Origins of Modern European History: From the European Renaissance to the French Revolution. TR: Rashid, Z., Mostafa, Dar Al Maaref, Cairo.

Gauchet, M. (2010). Religion in Democracy. Tr: hafiq Mohsen, Beirut: Arab Organization for Translation.

Ghallab, M. (2000). The Philosophy of the Greek. El-Anglo Egyptian Library, Cairo.

Habermas, J. (1989). The Structural Transformation of the Public Sphere. Tr: Thomas Burger, MIT Press, Cambridge.

Ibn Hisham, A. (1990). Biography of the Prophet Muhammad. Dar al-Kitab al-Arabi, Beirut.

Ibn Majah, M. (1996). Sunan Ibn Majah. Knowledge Library for Publishing and Distribution, Riyadh.

Kant, I. (1784). What is Enlightenment? Retrieved from http//www.allmondeberlin.de/What-is-Enlightenment.pdf

Kellner, D. (2014). Habermas, the Public Sphere and Democracy: A Critical Intervention. Retrieved from $\mathrm{http} /$ www.gseis.ucla.edu/faculty/kellner/papers/habermas.html

Khamis, H. A. (2013). Religion and Political Revolutions: The Egyptian Case as a Model. Journal of Strategic Perspectives, 1(3), 36-63.

Koehrsen, J. (2012). How Religious is the Public Sphere? A Critical Stance on the Debate on Public Religion and Post-Secularity. Acta Sociologica Review, 55(3), 273-288.

Kuhn. T. (1992). The Structure of Scientific Revolutions. TR: Shawki Galal The World of Knowledge Series, No. 168, Kuwait, p. 298.

Locke, J. (1999). Letter in Tolerance, First Letter. TR: Abu Senna, M. Alexandria Library, Alexandria.

Loobuyck, P., \& Rummens, S. (2011). Religious Arguments in the Public Sphere: Comparing Habermas with Rawls. Retrieved from https://www.scribd.com/document/116766946/Religious-Arguments-in-the-Public-Sphere

Lorimer, J. (1990). History of the Church. TR: Morjan, E. Dar El- Althaqafa, Cairo.

Mah, H. (2000). Phantasies of the Public Sphere ; Rethinking the Habermas of Historians. The Journal of Modern History, 72(1), 153-182.

Rahim, F. (2014). The Power of Religion in the Public Sphere. Journal of Al-Kufa, (1), Winter.

Robbins, T., \& Roberston, R. (1997). Church-State Relation: Tensions and Transitions. The Free Press, New York.

Russell, B. (2000). Religion and Science. TR: Ramses Awad, Dar al-Hilal, Cairo.

Russell, B. (2010). The History of Western Philosophy; Ancient Philosophy. TR: Zaki Naguib Mahmoud, General Egyptian Book Organization, Cairo.

Russell, B. (2010). A History of Western Philosophy; Ancient Philosophy. TR: Mahmoud, Z. El-Hi'a El-Msria El-Ama Ll-Ktab, Cairo.

Shennawi, A. (1982). Europe in the Early Modern Era. Anglo-Egyptian Library, Cairo.

Youssef, J. N. (1984). Studies in the History of the Middle Ages. University Youth Foundation, Alexandria.

\section{Notes}

Note 1. The clergy followed the system of the priesthood of the Christian churches, It did not appear only in the third century AD. See: Lorimer, J. (1990), History of the Church, tr: Morjan, E. Dar El- Althaqafa, Cairo, p. 123.

Note 2. In 1784, Emmanuel Kant wrote his famous essay, "What is Enlightenment?", Which was in the context of a discussion for a group of German thinkers, which held by a German magazine (at that time "Magazine of Berlin"). Kant's response to the question posed by a Protestant priest, Johann Friedrich Zollner, in his query on the definition of Enlightenment, when he said: "He did not find definition for the concept of Enlightenment by 
Enlightenment advocates, so how Kant call Enlightenment before he knows what is Enlightenment? ... So Kant wrote his famous essay in which he answers the question: What is Enlightenment? ... he pointed out that: for this Enlightenment, both for the individual and for the public, the freedom of "general use of the mind" is required in all fields. So, The "Public Sphere" as a one of the eighteenth century concepts, was meant the total number of people who meet in a public place and discuses some vital Isuues. See: Immanuel Kant, What is Enlightenment ?, 1784, on site: http: //www.allmondeberlin.de / What-is-Enlightenment.pdf

Note 3. There were a number of theories about the beginning and end of the Medieval Period. Twelve theories were developed about this. Some of them set its beginnings in 284 AD, with Diocletian taking over the Roman Empire. and others set its beginnings in $323 \mathrm{AD}$ when Emperor Constantine ascended the throne of the Roman Empire. The end of it was in 1453 with the advent of the Renaissance, the end of the 100-year war between England and France, and the transfer of Constantinople to the hands of the Ottoman Turks. However, no matter how different historians and thinkers visions about it, there is agreement that it has traditionally started from the 5th century and ended in the 15th century. See: Youssef, J. N. (1984), Studies in the History of the Middle Ages, University Youth Foundation, Alexandria. pp. 10-39.

Note 4. Secularism is derived from the Latin origin (Seculum) and means group or category. This concept has been used in the sense of the earthly world as opposed to the spiritual and moral world in the country inhabited by the Protestants. But, in countries that were inhabited by Catholics, such as France, the concept (Laicite) was used in the sense of secularism, a word taken from two Greek words: (Laos) that mean the people and (Laikos) that mean the general public versus the clergy. This Secularism has been translated into Persian, Nasouti, mundane, customary and earthly. See: El-Wa'zi, A. (2002), The Religious State: Reflections on Islamic Political Thought, tr: Rajaballah, H. Dar al-Ghadeer, Beirut, pp. 64-65.

Note 5. The Church in its view to the position of the Earth from other planets adopted the view of Aristotle from the thirteenth century AD, and the view of Ptolemy throughout the Middle Ages. Aristotle (384-322 BC), since the 4th century $\mathrm{BC}$, referred that the earth was still in the center of the world. Ptolemy came in the second century AD, and wrote his book known as "Almagest", and referred in it to the earth as the center of the universe, and the sun and the other planets rotate around it. Ghallab, M. (2000), the Philosophy of the Greek, El-Anglo Egyptian Library, Cairo, p. 298.

Note 6. The Church had prevented the teaching of the Copernicus system, and declared it invalid in all scientific and educational institutions which under its control. The Catholic Church continued to ban the teaching of the rotation of the earth until 1835. See: Russell, B. (2000), Religion and Science, tr: Ramses Awad, Dar al-Hilal, Cairo, P. 35.

Note 7. Some Countries with a large percentage of Muslims or Christians... .

Note 8. In Italy: the proportion of Italians that identify themselves as Roman Catholic was $81.2 \%$. "The Global Catholic Population". pewresearch.org. Pew Research Center. Retrieved 24 August 2014.

Note 9. Niccolò di Bernardo dei Machiavelli (Italia: 3 May 1469 - 21 June 1527) was an Italian diplomat, politician, historian, philosopher, humanist, and writer of the Renaissance period. See: https://en.wikipedia.org/wiki/Niccol\%C3\%B2_Machiavelli.

Note 10. Dogma is the fanaticism of a particular idea by a group without accepting the discussion or presenting any evidence refuted to discuss it or as the Greeks called "the intellectual stalemate". Namely, strictness in religious belief or ideological principle, or a subject that is not open to debate or suspicion.

Note 11. Habermas published his book "Structural Transformation of the Public Sphere" in German for the first time in 1961, but was not accepted and spread only in 1989 after it was published again after the translation in English.

Note 12. Ibn Majah, M. (1996) Sunan Ibn Majah, with commentary by Muhammad Nasir al-Din al-Albani, Hadith "Seeking knowledge ...", Hadith no. 224, Part of virtue of science and scholars and urge to seek knowledge, Knowledge Library for Publishing and Distribution, Riyadh, P. 56.

Note 13. Ibn Majah, Hadith no. 223, Part of virtue of science and scholars and urge to seek knowledge, Op.cit., P. 56.

Note 14. The Qur'an, Sūrat l-'alaq (The Clot), Verse: 1.

Note 15. The Qur'an, Sūrat l-qalam (The Pen), Verse: 1.

Note 16. The Qur'an, Sūrat 1-mujādilah (She That Disputeth), Verse: 11. 
Note 17. The Qur'an, Sūrat l-zumar (The Groups), Verse: 9.

Note 18. The Qur'an, Sūrat fățir (The Originator), Verse: 14.

Note 19. The Qur'an, Sūrat l-nạ̣l (The Bees), Verse: 43.

Note 20. In this, Dr. Ali Abdul Razek says: "If the Messenger founded a political state or started to establish it, why did his state leave many of the pillars of the state and the pillars of government? Why did not his regime define the appointment of judges and governors? Why did not he speak to his flock in the ruler system and in the Shura rules? and why he leave scientists in confusion and disorder in the government of the state? Abdul Razek, A. (1925), Islam and the Origins of Governance: A Study on the Caliphate and the Government in Islam, Egypt Press, Cairo, p. 57.

Note 21. The Qur'an, Sūrat l-ahzzāb (The Combined Forces), Verse: 6.

Note 22. The Qur'an, Sūrat l-a rāf (The Heights), Verse: 188.

Note 23. The Qur'an, Sūrat l-nūr (The Light), Verse: 54.

Note 24. The Qur'an, Sūrat 1-kahf (The Cave), Verse: 110.

Note 25. The Qur'an, Sürat 1-ra'd (The Thunder), Verse: 7.

Note 26. The Qur'an, Sūrat l-an'ām (The Cattle), Verse: 57.

Note 27. In this, al-Ashmawi says: "The rule of God be forever, but not of the understanding that the Kharijites claim, nor of the logic they claim, nor of the way they want to impose it, because such a method, logic, and the understanding diminishes the divine mandate and eliminates human will. And makes the punishment of the Outlaws of religion a vain, as it makes the day of resurrection a void. Why punishment; if a person has no will and does not do anything. See: Al-Ashmawi, M. S. (1996), Political Islam, Madbouli Library, Cairo, pp. 46-47.

Note 28. Al-Ashmawi said: "The rule in the era of the Prophet "Muhammed" was the rule of God, as long as the Islamic understanding believes that the Prophet "Muhammed" was working under the guidance of revelation and under his control and revelation began and established and corrected and agreed the be silence ... But after the Prophet, all people are equal, none of them is inspired by a clear and direct revelation as the Prophet's revelation, and then their rule is the rule of the people who afflict in it, and the right return for them alone. , And make mistakes in it, so they are wrong in it, and any statement other than that is intended to infuriate the ruler or holiness over the tyrant, and also aims to fortify the work of the ruler or call the Baghi (Disobedience) of any control or examination or accountability. See Muhammad Saeed al-Ashmawi, Op. Cit., P. 53.

Note 29. Al-Ashmawi said: "After the death of the Prophet, Abu Bakr became the first Khalifa and the word of Khalifa carries two means: who succeeds a person legal or realistic succession, and it means the successor of a person in time. The first generation of Muslims intended to call the word Khalifa on Abu Bakr The second meaning, which refers that he follows the Prophet in time; that is, he came after him, especially since there is no caliphate in prophecy because prophecy does not inherit; nor the succession of the Prophet in his system of rule, because this rule is specific to him alone. The caliphs are seen as successors of the prophet and in particular in certain characteristics of prophecy." See Muhammad Saeed al-Ashmawi, Op. Cit., P. 114.

Note 30. The Qur'an, Sūrat 1-nisāa (The Women), Verse: 65.

Note 31. The Qur'an, Sūrat l-māidah (The Table spread with Food), Verse: 42.

Note 32. In this, Dr. Al-Jabri said: "It seems clear that the issue of the relationship between religion and state was not raised in the time of the Prophet nor in the time of the Caliphs, but in the time of the Prophet, the whole effort was aimed at spreading the religion and defending it, and it was all in this regard to the prophet Muhammad, the revelation that was descended on him, And the diligence of his friends effort, none of them viewed to this matter as a kingdom ... nor a state ... Muslims did not consider in the time of the prophet Muhammad friends Islam as a state ... they regarded it as a religion that seals all religions, which will remain until the Day of Judgment, so they linked it with (nation) and attributed the nation to Islam and the Prophet of Islam: the nation of Islam, the nation of Muhammad." Al-Jabri, M. (1997), Religion and the State and the Application of Sharia, Center for Arab Unity Studies, Beirut.

Note 33. The Qur'an, Sūrat āl 'im'rān (The Family of Imrān), Verse: 110.

Note 34. The Qur'an, Sūrat āl 'im'rān (The Family of Imrān), Verse: 159.

Note 35. The Qur'an, Sūrat 1-shūrā (Consultation), Verse: 38.

Note 36. The Qur'an, Sūrat l-ahzzāb (The Combined Forces), Verse: 6. 
Note 37. The Qur'an, Sūrat 1-māidah (The Table spread with Food), Verse: 6.

Note 38. The Qur'an, Sūrat 1-māidah (The Table spread with Food), Verse: 55.

\section{Copyrights}

Copyright for this article is retained by the author(s), with first publication rights granted to the journal.

This is an open-access article distributed under the terms and conditions of the Creative Commons Attribution license (http://creativecommons.org/licenses/by/4.0/). 